Medicina Farmacêutica

\section{QUEM DEVE CUIDAR DA CAPACITAÇÃO DOS MEMBROS DOS COMITÊS DE ÉTICA?}

O objetivo da pesquisa clínica é o avanço dos conhecimentos para melhorar a vida de todas as pessoas. O interessado final é a coletividade, o todo, a humanidade. Portanto, o compromisso deve ser assumido por todos e cada um deve contribuir com a sua parcela para o benefício de todos.

Todas as pesquisas em seres humanos realizadas no Brasil devem ter um projeto aprovado por um Comitê de Ética em Pesquisa (CEP), que é a unidade básica do sistema CEP - CONEP (Comissão Nacional de Ética em Pesquisa). Ele é parte de uma instituição que é o maior interessado em ter um CEP capaz. A CONEP, como instância superior do sistema, é a responsável direta pelo seu adequado funcionamento. Deve zelar pela competência dos membros das unidades básicas (CEPs), tanto quanto as instituições que as abrigam. Um dos principais objetivos da Resolução 196/96 é a maior participação possível da coletividade. Desse modo, o sistema deve agregar outros componentes, ou "parceiros", tais como as universidades e outras instituições públicas ou privadas (entidades financiadoras de pesquisa, sociedades científicas, associações de profissionais etc). O problema se situa no tipo de relação entre esses "parceiros": exclusão, divisão, litígio ou somatória? A relação ideal é a somatória de esforços para se atingir o objetivo comum. Esta relação implica em respeito pelas diferenças, mas, principalmente, dar de si em vez de apenas reivindicar direitos.

No CEP da Santa Casa de São Paulo, temos tido experiências inovadoras. Cada projeto é analisado por três membros do CEP. O relator escreve o parecer e o lê na reunião, enquanto dois correlatores devem ler o projeto e comentá-lo após a leitura. Os correlatores, além da oportunidade de discutirem o projeto com o relator, geralmente mais experiente, observarão também o modo como ele escreve o parecer consubstanciado. Introduzimos 10 suplentes para suprir as ausências dos titulares em férias, congressos etc. Também nos valemos de membros "ad hoc", precedentes de departamentos, serviços e cursos atuantes na Santa Casa.

Daniel Romero Muñoz

\section{Referência}

I. Brasil. Ministério da Saúde. Resolução n.196/96 outubro 1996

\section{Obstetricia}

COMO ADMINISTRAR O ÁCIDO FÓLICO NO PERÍODO PERICONCEPCIONAL?

A suplementação vitamínica com o ácido fólico constitui-se em uma das possibilidades de prevenção de malformações fetais graves, principalmente dos defeitos de fechamento do tubo neural (DFTN). A incidência relatada na literatura internacional dos DFTN gira em torno de $1 / / 000$ a 8/I000 nascidos vivos 23,4 ; no Brasil estima-se que a taxa oscile em torno de 1,6/ 1000 nascidos vivos'. A recorrência fica ao redor de $2 \%$ a $3 \%$. Sua etiologia é multifatorial em $88 \%$ das vezes $^{1,2}$. Em $0,5 \%$, correspondem a defeito genético nas enzimas envolvidas no metabolismo do folato (hiperhomocisteinemia). São consideradas pacientes de risco as usuárias de drogas depletoras de folatos (anticonvulsivantes), as diabéticas tipo I e a gemelaridade ${ }^{1,2}$. Estudos pioneiros observacionais, nas décadas de 50 e 60, constataram diminuição da prevalência dos DFTN com a administração de ácido fólico, bem como a relação do baixo nível de ácido fólico com os DFTN². Pesquisa importante para o entendimento das alterações que resultam no distúrbio da distribuição do folato foi elaborada por Bunduki et al. em 1995', que puderam demonstrar a normalidade dos níveis séricos de folato. Por outro lado, o folato tissular, representado pelos níveis eritrocitários, em pacientes que tiveram fetos com DFTN, encontravam-se em níveis baixos quando comparados com os das pacientes do grupo controle. A etiologia do nível tecidual mais baixo nas gestantes com fetos portadores de DFTN é, ainda, controverso, podendo estar ligada a defeito de estocagem'. Porém, a complexidade do metabolismo do ácido fólico dificulta a plena compreensão da sua participação na embriogênese. Com o intuito de se prevenir os DFTN, importantes estudos intervencionistas (suplementação alimentar e administração periconcepcionais de ácido fólico), mostraram diminuição na incidência em regiões com grande prevalência ${ }^{2}$. Entre as várias possibilidades de intervenção propostas, o enriquecimento alimentar, a orientação dietética e a suplementação de ácido fólico são recomendadas. Esta última parece ser o método mais efetivo e prático de se prevenir os DFTN que, sendo a forma sintética da vitamina, é a mais estável e com maior biodisponibilidade. Com a administração de 0,4 mg/dia é descrito decréscimo de $50 \%$ a $70 \%$ na incidência dos DFTN2.

Segundo referências da literatura (mesmo em países do chamado $1^{\circ}$ mundo), a estratégia em se administrar ácido fólico no período periconcepcional para a prevenção dessa malformação fetal esbarra na constatação de que $50 \%$ das gestações não são planejadas e na baixa aderência das pacientes no uso da medicação ${ }^{4}$. Tal fato aponta a necessidade de amplo programa de orientação da classe médica e da população por meio de uma divulgação irrestrita, tanto na imprensa científica, quanto na leiga. Preconiza-se o início da administração do ácido fólico três meses antes da concepção. Durante a gestação deve ser mantida até o terceiro mês, suspendendo-o ao completar 12 semanas. A dose aconselhada é de 0,4 a $0,8 \mathrm{mg} / \mathrm{dia}^{2}$. Quando houver antecedente do DFTN, a dosagem recomendada é de $4,0 \mathrm{mg} / \mathrm{dia}$, sendo esta considerada dose farmacológica.

Marco Antonio Borges Lopes Victor BUNdUKI Marcelo Zugaib
Referências

I. Bunduki V, Dommergues M, Zittoun J, Marquet J, Muller F, Dumez Y. Maternal-fetal folates status and neural tube defects: a case control study. Biol Neonate 1995; 67(1): 154-9.

2. Czeizel AE. Primary prevention of neural-tube defects and some others major congenital abnormalities: recommendations for the appropriate use of folic acid during pregnancy. Pediatr Drugs 2000; 2(6):437-49.

3. Kirly RS. Fortification of food with folic acid. N Engl J Med 2000; 34(13):971.

4. Van der Pal-de Bruin RM. The Dutch Folic Acid Campaign have the goals been achieved? Pediatr Epidemiol 2000; 14(2): 1 I 1-7.

\section{Pediatria}

INSULINA EM CRIANÇAS EM ESTADO GRAVE: HÁ DISTÂNCIA

\section{ENTRE A TEORIA E A PRÁTICA?}

Crianças e adultos em estado clínico grave, particularmente aqueles portadores de infecção sistêmica ou no período pós-operatório de cirurgias de grande porte, apresentam aumento do catabolismo protéico e tendência à hiperglicemia, em graus de intensidade proporcionais à gravidade da doença. Há muitos anos têm sido relatados os efeitos benéficos da insulina exógena nestas situações. A administração endo venosa, contínua, do hormônio em pacientes com infecção grave ou após grandes cirurgias, promoveria normalização dos níveis glicêmicos e redução do catabolismo protéico. A questão tem merecido ainda considerações na literatura médica atual ${ }^{1,2}$. Na prática, pudemos comprovar tais fatos, tanto em animais de experimentação quanto em crianças. No entanto, tais benefícios não tiveram qualquer expressão clínica ou no que tange à redução dos índices de mortalidade. Por outro lado, constatamos alguns problemas decorrentes da infusão contínua de glicose em crianças, e que devem ser enfatizados:

- ocorrem grandes variações dos níveis de glicemia, com freqüentes episódios de hipoglicemia grave,

- do ponto de vista prático, ocorrem freqüentes erros de dosagem da insulina a ser administrada, particularmente em crianças pequenas,

- a insulina pode ser adsorvida na parede do frasco de infusão, com redução significativa de sua atividade terapêutica.

A literatura, até o presente, não mostrou que a utilização na insulina, nestas condições, promoveria redução nos índices de mortalidade. Portanto, julgamos que não há evidências que justifiquem o uso de insulina exógena no tratamento de crianças em hipercatabolismo.

UENIS TANNURI

Referências

I.Agus MSD, Javid P, Ryan DP, Jaksic T. Intravenous insulin decreases protein breakdown in infants on extracorporeal membrane oxygenation. J Pediatr Surg 2004; 39:839-84.

2.Hall NJ, Peters M, Eaton S, Pierro A. Hyperglycemia is associated with increased morbidity and mortality rates in neonates with necrotizing enterocolitis. J Pediatr Surg 2004; 39:898-901. 